\title{
EFFECT OF IRRIGATION WATER QUALITY ON SOME SOIL PROPERTIES, PRODUCTIVITY OF SOME WHEAT CULTIVARS AND THEIR CONTENTS OF HEAVY METALS Nassr, M.M.I.; E.A. Moursi and M.M. Kassab Soils, Water and Environment Research Institute, Agric. Res. Center, Giza, Egypt
}

\begin{abstract}
Two lyzimeter investigations were carried out at Sakha Agricultural Research Station, Kafr El-Sheikh Governorate. The site of this investigation is located at $31^{\circ} 05$ $\mathrm{N}$ latitude and $30^{\circ} 56^{-} \mathrm{E}$ longitude with an elevation of about 6 meters above mean sea level. This location represents the conditions of the North Middle Nile Delta region. The experiment was conducted during the two successive winter growing seasons $2012 / 2013$ and $2013 / 2014$ to investigate the impact of irrigation water quality for longterm on some soil characteristics, productivity of some wheat cultivars and also their contents of heavy metals. Wheat cultivars were four, Misr-2, Misr-1, Sakha 94 and Sakha 93 in the two growing seasons to study the content of their grains and straw of some heavy metals such as $\mathrm{Pb}, \mathrm{Cd}, \mathrm{Ni}, \mathrm{Mn}, \mathrm{Zn}$ and $\mathrm{Cu}$ as affected by different water qualities since 1987. The irrigation water qualities were: $W_{1}$, (Nile Water, good water quality), $W_{3}$ (drainage water, relatively poor water quality) and $W_{2}$ (mixed water, $50 \%$ $W_{1}+50 \% W_{3}$ ). A split plot design with four replicates was used where; the main plots were assigned by irrigation water quality. While, sub main plots were assigned for wheat cultivars.

The main results in this present study can be summarized as follows:

- The main values of soluble ions $\mathrm{Cl}^{-}, \mathrm{SO}_{4}{ }^{=}, \mathrm{Ca}^{++}, \mathrm{Mg}^{++}, \mathrm{Na}^{+}, \mathrm{K}^{+}$and determined $\mathrm{ECe}$, measured $\mathrm{pH}$ and calculated $\mathrm{SAR}$ were increased by using low irrigation water quality $W_{3}$ in comparison with $W_{1}$ and $W_{2}$. Generally, the mean values of the abovementioned studied parameters can be descended in order $W_{3}>W_{2}>W_{1}$ before planting. The same trend was observed after planting process but the mean values were higher than those before planting.

- Concerning grain yield, the mean values can be descended in order Misr-2 > Misr1 > Sakha 94 > Sakha 93 of 452, 428, 413 and 366 (gm/Lyz.). The same trend was obtained for straw yield but the mean values are 1156, 1128, 1116 and 1013 (gm/Lyz.), respectively. Increasing the mean values of Misr-2 yields in comparison with other studied cultivars; it means that cultivar is more tolerant to the mixed and drainage water when use for irrigation than other cultivars.

- Regarding the effect of irrigation water quality, the highest mean values for grain and straw yields were recorded under $W_{1}$ comparing with $W_{2}$ and $W_{3}$. Concerning, DTPA-extractable $\mathrm{Pb}, \mathrm{Cd}, \mathrm{Ni}, \mathrm{Mn}, \mathrm{Zn}$ and $\mathrm{Cu}$, the highest mean values were recorded under $W_{3}$ comparing with $W_{1}$ and $W_{2}$ before planting. The same trend was obtained after planting but the mean values were higher than those before planting.

- Straw content of the studied heavy metals were higher than that of corresponding grains for studied water quality treatments. Wheat straw and grain contents of $\mathrm{Pb}$, $\mathrm{Cd}, \mathrm{Ni}, \mathrm{Mn}, \mathrm{Zn}$ and $\mathrm{Cu}$ were higher under $\mathrm{W}_{3}$ in comparison with $\mathrm{W}_{1}$ and $\mathrm{W}_{2}$. The grains of wheat cultivar Misr-2 were the lowest in their contents of these heavy metals followed by those of Misr-1. The straw of Misr-2 had also the lowest content of $\mathrm{Cd}, \mathrm{Ni}$ and $\mathrm{Zn}$ when drainage water was used for irrigation.
\end{abstract}


So, in conclusion, the study recommend planting the cultivar Misr-2 for irrigation with drainage water because it is the least affected by heavy metals and salinity.

Keywords: wheat, water qualities, heavy metals.

\section{INTRODUCTION}

Wheat is the most important cereal crop in Egypt and worldwide. It considers one of the main components of Egyptian food diet. The local production is not sufficient to meet the local requirements for increasing population. Egyptian production is about 7.4 million tons of wheat grain, but the national consumption was around 14.0 million tons according to the last statistics (2010). The average production of $18.12 \mathrm{ardab} / \mathrm{fed}$. (ardab=150 kg), (Anonymous, 2007). It is great importance to increase total wheat production by increasing wheat cultivated area or by planting high yielding cultivars, to narrow the wide great gap between production and consumption as abovementioned before.

Nowadays, fresh water resources are limited to meet annual needs of irrigation. Hence, non-conventional water resources i.e., drainage water, underground water and treated municipal wastewater are reused especially in the agricultural utilization. Under limitation of fresh water resources and importance of wheat crop. So, using low quality water in agricultural sector will be a must particularly in these areas which lies at the tail end of the Nile River like some regions in Kafr El-Sheikh Governorate. An area of approximately one million faddan in the Nile Delta depends upon drainage water in irrigation (El-Hawary, 2003). Mostafa (2001b) reported that irrigation with Nile water gave wheat grain yield of 2.29 tons/fed. compared to 2.26 ton/fed. and 2.21 ton/fed. for drainage and sewage water, respectively. While, El-Saady (1991) obtained the highest straw and grain yield when wheat was irrigated by Nile water alternated with drainage water.

Using low quality water in agriculture has bad effects on both soil properties and planting crop by either increasing their contents of heavy metals which affects badly on the human being health or by increasing salinity levels, where increasing water salinity level decreased dry matter production of Sakha 69 wheat cultivar (Mostafa, 2001a). Zein et al. (2012), Atwa et al. (2013) and Seema Sahay et al. (2013), reported that using drainage water for irrigation increased $\mathrm{ECe}, \mathrm{SAR}$, soluble $\mathrm{Na}^{+}, \mathrm{Mg}^{++}, \mathrm{SO}_{4}=$ and $\mathrm{Cl}^{-}$in soil paste extract, total and available $\mathrm{Pb}, \mathrm{Cd}$ and $\mathrm{Ni}$ than that of mixed and Nile water. Heavy metal toxicity is one of major current environmental health problems and potentially dangerous due to bioaccumulation. Therefore, heavy metals contamination of soils and plants has become an increasing problem.

A number of factors including climate, atmospheric deposition, the nature of soil on which the plant grown and the maturity degree of plant and harvesting time influence the heavy metals concentration in plants (Voutsa et al., 1996 and Abeguynrin et al., 2013). Also, heavy metals concentration has affected by a lot of factors such as application of fertilizer, sewage sludge and irrigation with low quality waters (Frost and Ketchum, 2000). During recent 
years, studies on toxic effects of heavy metals especially $\mathrm{Cd}$, on crop plants are being received a wide attention (Boussamo et al., 1999). So, the main targets of this study were to investigate the effect of irrigation water quality on:

1) Productivity of some wheat cultivars,

2) Some soil properties and,

3) Heavy metal contents in the studied soil and wheat cultivars.

\section{MATERIALS AND METHDOS}

Two lyzimeter experiments were conducted at Sakha Agricultural Research Station, Kafr El-Sheikh Governorate, Egypt, during the two successive winter growing seasons 2012/2013 and 2013/2014 to study the effect of irrigation water quality for long-term on some soil properties, productivity of some wheat cultivars and their contents of heavy metals. The station is situated at $31^{\circ} 05^{\circ} \mathrm{N}$ latitude and $30^{\circ} 56^{\circ} \mathrm{E}$ longitude with an elevation of about 6 meters above mean sea level. It represents the conditions and circumstances of the Northern part of the Nile Delta region. A split plot design with four replicates was used in this present study where the main plots were assigned by three water quality treatments which were $\mathrm{W}_{1}$ (irrigation with the Nile water), $W_{3}$ (polluted drainage water, water from drain No. 7) at order after disposal of untreated oil and soap factor effluents and urban and municipal wastes discharged, which were analyzed for total soluble salts, soluble cations and anions and heavy metals content which presented in Table (1) and $W_{2}$ (mixed water; $50 \% \mathrm{~W}_{1}+50 \% \mathrm{~W}_{3}$ ). While, submain plots were assigned by wheat cultivars Misr-2, Misr-1, Sakha 93 and Sakha 94. The studied heavy metals contents in both grains and straw of wheat cultivars were $\mathrm{Pb}, \mathrm{Cd}, \mathrm{Ni}$, $\mathrm{Mn}, \mathrm{Zn}$ and $\mathrm{Cu}$. This investigation was carried out in concrete lyzimeters with dimensions $(100 \times 70 \times 90 \mathrm{~cm})$ filled with clay soil $(56.29 \%$ clay, $17.71 \%$ silt and $26.00 \%$ sand), since 1987 . In the two growing seasons; the four wheat cultivars were planted on $15^{\text {th }}$ November and $18^{\text {th }}$ November at the rate of 100 grains/lyzimeter. Plants were harvested on $25^{\text {th }}$ and $29^{\text {th }}$ May in the first and second growing seasons, respectively. Weights of grains and straw were recorded as gm/lyzimeter.

All agricultural practices were performed according to the recommended for the crop and the studied area except the tested treatments (irrigation water quality and wheat cultivars).

At harvesting, representative grain and straw samples were collected for analysis; dry ashing technique was used for samples digestion as described by Chapman and Pratt (1961). Before planting and after harvesting, soil samples were taken from each lyzimeter for chemical analysis; total soluble salts, soluble cations and anions in soil-paste extract according to Richards (1969). Soil samples were DTPA extracted and Cd, $\mathrm{Pb}, \mathrm{Ni}, \mathrm{Mn}, \mathrm{Zn}$ and $\mathrm{Cu}$ were determined using the atomic absorption spectrophotometer according to Lindsay and Norvell (1978). 
Table (1): Chemical analysis and heavy metals content of Nile and drainage water.

\begin{tabular}{|c|c|c|c|c|c|c|c|c|c|c|c|c|c|}
\hline \multirow[t]{2}{*}{ Water qualities } & \multicolumn{4}{|c|}{ Anion (meq/L) } & \multicolumn{4}{|c|}{ Cations $(\mathrm{meq} / \mathrm{L})$} & \multirow{2}{*}{$\begin{array}{l}\mathrm{EC}, \\
\mathrm{dS} / \mathrm{m}\end{array}$} & \multirow[t]{2}{*}{ SAR } & \multirow{2}{*}{\multicolumn{2}{|c|}{$\begin{array}{l}\text { Water } \\
\text { class }^{\star \star}\end{array}$}} & \multirow[t]{2}{*}{$\mathrm{pH}$} \\
\hline & $\mathrm{CO}_{3}{ }^{=}$ & $\mathrm{HCO}_{3}^{-}$ & $\mathrm{Cl}^{-}$ & $\mathrm{SO}_{4}{ }^{=}$ & $\mathrm{Ca}^{++}$ & $\mathrm{Mg}^{++}$ & $\mathrm{Na}^{++}$ & $\mathbf{K}^{+}$ & & & & & \\
\hline Nile water & - & 3.54 & 0.94 & 0.78 & 1.68 & 1.60 & 1.76 & 0.22 & 0.43 & 1.37 & & & 7.25 \\
\hline Drainage water & - & 5.25 & 12.91 & 4.37 & 4.88 & 3.35 & 13.76 & 0.54 & 1.89 & 6.87 & & & 8.40 \\
\hline \multicolumn{14}{|c|}{ Heavy metals content (ppm) in water samples } \\
\hline \multicolumn{3}{|c|}{ Water quality } & \multicolumn{2}{|c|}{$\mathrm{Cd}$} & \multicolumn{2}{|c|}{$\mathrm{Pb}$} & \multicolumn{2}{|c|}{\begin{tabular}{l|l}
$\mathrm{Ni}$ & \\
\end{tabular}} & $\mathrm{Mn}$ & \multicolumn{2}{|c|}{$\mathrm{Zn}$} & & $\mathrm{Cu}$ \\
\hline \multicolumn{3}{|c|}{ Nile water } & \multicolumn{2}{|c|}{0.004} & \multicolumn{2}{|c|}{0.300} & \multicolumn{2}{|l|}{0.021} & 0.011 & \multicolumn{2}{|c|}{0.010} & & .012 \\
\hline \multicolumn{3}{|c|}{ Drainage water } & \multicolumn{2}{|c|}{0.032} & \multicolumn{2}{|c|}{0.430} & \multicolumn{2}{|l|}{5.526} & 0.337 & \multicolumn{2}{|c|}{0.267} & & .053 \\
\hline \multicolumn{3}{|c|}{$\begin{array}{l}\text { Critical level (according to } \\
\text { FAO 1985) }\end{array}$} & \multicolumn{2}{|c|}{0.010} & \multicolumn{2}{|c|}{5.000} & 0.200 & \multicolumn{2}{|c|}{0.200} & \multicolumn{2}{|c|}{0.010} & \multicolumn{2}{|c|}{0.200} \\
\hline
\end{tabular}

${ }^{\star \star}$ Average of 5 samples

*** According to Richards (1969)

\section{Statistical analysis:}

Data are subjected to statistical analysis according to Snedecor and Cochran (1980).

\section{RESULTS AND DISCUSSION}

\section{Nile and drainage water evaluation:}

Chemical characteristics of both Nile and drainage waters used for irrigating planted wheat cultivars were shown in Table (1). Data clearly illustrated that the mean value of EC for the water of the Nile River is 0.43 $\mathrm{dS} / \mathrm{m}$ and for SAR value is 1.37 . According to Richards classification, the Nile water is $\mathrm{C}_{2}-\mathrm{S}_{1}$; this means that it is medium salinity and low sodicity (Richards, 1969). While, the mean EC values for drainage water, is 1.89 $\mathrm{dS} / \mathrm{m}$ and SAR is 6.89 . This means that, this kind of water is high salinity and medium sodicity $\left(\mathrm{C}_{3}-\mathrm{S}_{1}\right)$, Richards (1969). This water cannot be used in soils with restricted drainage system. Also, the soil with adequate drainage requires special management of salinity control and special crops with a good salt tolerance. From abovementioned analysis for both the two types of water, it can be concluded that, the water of the Nile River has a good quality. On the other hand, drainage water has a poor quality to use in irrigation purpose. So, the mixed water will be intermediate between the two types of water (good and low quality waters). Data in (Table 1) clearly showed that all values of cations, anions, EC and SAR were higher in drainage water in comparison with the Nile water. Concerning the content of heavy metals in the two types of waters, the mean values for all heavy metals content are higher for drainage water comparing with the Nile water. Also, the contents of all these heavy metals in Nile water still less than critical levels but in drainage water some heavy metals contents such as ( $\mathrm{Cd}, \mathrm{Ni}, \mathrm{Mn}$ and $\mathrm{Zn}$ ) were higher than critical levels as shown in Table (1) but content of $\mathrm{Pb}$ and $\mathrm{Cu}$ less than critical levels.

\section{Effect of irrigation water quality on some chemical characteristics of the studied soil:}

Data presented in Table (2) clearly illustrated that irrigation water quality has a great effect on some chemical characteristics of the studied soil. Generally, the mean values of soluble cations, anions, EC, pH and SAR were 
increased in soil after performing investigation (after harvesting) in comparison with before planting process for all the studied chemical characteristics of the soil. Under all irrigation water qualities, the mean values before planting are $3.06,21.92,28.75,19.28,11.78,21.90$ and $0.56 \mathrm{meq} / \mathrm{L}$ and $5.44 \mathrm{dS} / \mathrm{m}, 8.12$ and 5.42 for $\mathrm{HCO}_{3}{ }^{-}, \mathrm{Cl}^{-}, \mathrm{SO}_{4}{ }^{\circ}, \mathrm{Ca}^{++}, \mathrm{Mg}^{++}, \mathrm{Na}^{+}, \mathrm{K}^{+}, \mathrm{EC}$, $\mathrm{pH}$ and SAR. While the corresponding values after harvesting are 4.91, $24.47,31.25,20.82,12.80,24.39,0.64,5.73,8.19$ and 5.83 , respectively. Data in Table 2 illustrated that irrigation water quality has a great effect on the studied soil characteristics. The highest mean values either before planting or after harvesting were recorded under $W_{3}$ (poor quality water) in comparison with $W_{1}$ and $W_{2}$. On the contrary, the lowest mean values were recorded under $W_{1}$ (good water quality) before planting and after harvesting. This might be attributed to increasing the salt concentration in the poor quality water $\left(W_{3}\right)$ in comparison with other irrigation water qualities $W_{1}$ and $W_{2}$ which have a low concentration. These results are in a great harmony with those obtained by Zein et al. (2012) and Saleh et al. (2013).

Table (2): Soil chemical analysis (soil paste extract) as affected by irrigation water quality.

\begin{tabular}{|c|c|c|c|c|c|c|c|c|c|c|c|}
\hline \multirow{2}{*}{$\begin{array}{l}\text { Water } \\
\text { qualities }\end{array}$} & \multicolumn{4}{|c|}{ Anions (meq/L) } & \multicolumn{4}{|c|}{ Cations (meq/L) } & \multirow{2}{*}{$\begin{array}{c}E C, \\
\mathrm{dS} / \mathrm{m}\end{array}$} & \multirow{2}{*}{ pH } & \multirow{2}{*}{ SAR } \\
\hline & $\mathrm{CO}_{3}=$ & & $\mathrm{Cl}^{-}$ & $\mathrm{SO}_{4}=$ & $\mathrm{Ca}^{++}$ & & $\mathrm{Na}^{++}$ & $\mathrm{K}^{+}$ & & & \\
\hline \multicolumn{12}{|c|}{ Before planting } \\
\hline$W_{1}$ & - & 3.28 & & 18.59 & 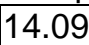 & & 10.20 & 0.48 & 3.45 & 8.02 & 2.99 \\
\hline $\mathrm{W}_{2}$ & - & 3.00 & & 0.72 & 20.34 & 12.94 & 25.44 & 0.55 & 5.88 & & 3.24 \\
\hline $\mathrm{W}_{3}$ & - & 2.90 & & 36.93 & 23.40 & 13 & 30. & 0.64 & 6.98 & 1 & 7.03 \\
\hline Mean & - & 3.06 & & 28.75 & 19.28 & 11.78 & & 0.56 & 5.44 & & 5.42 \\
\hline \multicolumn{12}{|c|}{ After harvesting } \\
\hline$W_{1}$ & - & 4.57 & & 0.94 & 14.20 & & & 0.59 & 3.66 & 8.12 & 3.82 \\
\hline & - & 4 & & 2.64 & 22.3 & & & 0.61 & 6.34 & 8.2 & .45 \\
\hline & - & 5.23 & & & 25.9 & & & 0.73 & 7.18 & 8.24 & 7.21 \\
\hline Mean & - & 4.91 & $\mid<4.41$ & & & 12.80 & 24.39 & 0.64 & 5.73 & 8.19 & 5.83 \\
\hline
\end{tabular}

pH was measured in 1:2.5 soil : water suspension

\section{Effect of irrigation water quality on grain and straw yields of some wheat cultivars: \\ Grain yield (gm/lyzimeter)}

Data in Table (3) clearly showed that under all irrigation water quality treatments $\left(W_{1}, W_{2}\right.$ and $\left.W_{3}\right)$. The highest mean values for grain yield were recorded under wheat cultivar Misr-2, then Misr-1, after that Sakha 94 and finally Sakha 93. The mean values are 452, 428, 413 and $366 \mathrm{gm} / \mathrm{lyzimeter}$, respectively. Increasing the mean values of grain yield for the studied wheat cultivars as mentioned before. This might be attributed to physiological, anatomical, agronomical characteristics, growth behavior for each cultivar and its tolerance to these conditions under the studied area. These results are in a great agreement with those obtained by Zein et al. (2002) and Zein et al. (2012). 
Concerning with the effect of irrigation water quality on grain yield of the studied wheat cultivars. The highest mean values were recorded under $W_{1}$ (good water quality) comparing with other water quality treatments $\left(W_{2}\right.$ and $\left.W_{3}\right)$. On the other hand, the lowest mean values were recorded under irrigation water quality $W_{3}$. The mean values under $W_{1}$ are $491,479,440$ and $393 \mathrm{gm} / \mathrm{lyzimeter}$ for wheat cultivars Misr-2, Misr-1, Sakha 94 and Sakha 93, respectively. The corresponding values under $W_{3}$ are 421, 397, 396 and 341 gm/lyzimeter for wheat cultivars Misr-2, Sakha 94, Misr-1 and Sakha 93, respectively. Increasing the mean values of grain yield under $W_{1}$ comparing with $W_{2}$ and $W_{3}$ might be due to decreasing salt concentration in irrigation water $W_{1}$ and hence, improving soil properties. Consequently, increasing uptake rate of soil water and nutrients. Therefore, forming strong and healthy plants which give high and good yield comparing with mixed water and low quality one which have a bad effect on soil properties and hence, growing plants that give a low yield. These findings are in the same line with those reported by Abd-allah (1995), El-Mowelhi et al. (1995), Amany, M. Sallam et al. (2008), Zein et al. (2012) and Seema Sahay et al. (2013).

\section{Straw yield (gm/lyzimeter):}

Presenting data in Table (3) showed that, the mean values of straw yield were clearly affected by both wheat cultivars and irrigation water quality treatments. Concerning with the effect of wheat cultivar under all irrigation water quality treatments. The highest mean values were recorded under wheat cultivar Misr-2, followed by Misr-1, then Sakha 94 and finally Sakha 93 and the mean values are 1156, 1128, 1116 and $1013 \mathrm{gm} /$ lyzimeter, respectively.

Table (3): Effect of irrigation water quality on grain and straw yields (gm/lyz.) of some wheat cultivars in 2012/2013 and 2013/2014.

\begin{tabular}{|c|c|c|c|c|c|c|c|c|}
\hline \multirow{2}{*}{ Wheat cultivars } & \multicolumn{2}{|c|}{ Misr-2 } & \multicolumn{2}{c|}{ Misr-1 } & \multicolumn{2}{c|}{ Sakha 93 } & \multicolumn{2}{c|}{ Sakha 94 } \\
\cline { 2 - 9 } Water quality & $\begin{array}{c}\text { Grain } \\
\text { yield }\end{array}$ & $\begin{array}{c}\text { Straw } \\
\text { yield }\end{array}$ & $\begin{array}{c}\text { Grain } \\
\text { yield }\end{array}$ & $\begin{array}{c}\text { Straw } \\
\text { yield }\end{array}$ & $\begin{array}{c}\text { Grain } \\
\text { yield }\end{array}$ & $\begin{array}{c}\text { Straw } \\
\text { yield }\end{array}$ & $\begin{array}{c}\text { Grain } \\
\text { yield }\end{array}$ & $\begin{array}{c}\text { Straw } \\
\text { yield }\end{array}$ \\
\hline $\mathrm{W}_{1}$ & 491 & 1203 & 479 & 1145 & 393 & 1060 & 440 & 1138 \\
\hline $\mathrm{W}_{2}$ & 445 & 1143 & 409 & 1120 & 363 & 1053 & 401 & 1124 \\
\hline $\mathrm{W}_{3}$ & 421 & 1121 & 396 & 1119 & 341 & 927 & 397 & 1086 \\
\hline Mean & 452 & 1156 & 428 & 1128 & 366 & 1013 & 413 & 1116 \\
\hline LSD 5\% & 35.91 & 162.4 & 35.91 & 162.4 & 35.91 & 35.91 & 35.91 & 35.91 \\
LSD 1\% & 46.57 & 221.6 & 46.57 & 221.6 & 221.6 & 221.6 & 221.6 & 221.6 \\
\hline
\end{tabular}

Regarding the effect of irrigation water quality, the highest mean values were recorded under irrigation water quality $\mathrm{W}_{1}$ and the mean values are 1203, 1145, 1138 and $1060 \mathrm{gm} /$ lyzimeter for Misr-2, Misr-1, Sakha 94 and Sakha 93, respectively. On the contrary, the lowest mean values were recorded under irrigation water quality $\mathrm{W}_{3}$ and the mean values are 1121, 1119, 1086, 927 gm/lyzimeter for Misr-2, Misr-1, Sakha 94 and Sakha 93, respectively. In general, the increases of water salinity levels decreased the straw yield for the investigated wheat cultivar. These results are in a great harmony with those obtained by FAO (1973), El-Hawary (2003), Amany, Sallam et al. (2008); Zein et al. (2012) and Abeguynrin et al. (2013).

Data in Table 3 declared that the lowest mean values under all wheat cultivars and irrigation water quality treatments was recorded under wheat 
cultivar Sakha 93 with irrigation water quality $W_{3}$. These results are in a great agreement with those reported by Zein and Bader (2003), Amany, Sallam et al. (2008) and Zein et al. (2012).

\section{Heavy metals content:}

Nile and drainage waters:

Data in Table (1) clearly showed that, the mean values of all studied heavy metals were greatly affected by kind of water used. Generally, all studied heavy metals contents are less in Nile water comparing with drainage water and also less than critical levels. The mean values for these heavy metals in the Nile water are $0.004,0.300,0.021,0.011,0.010$ and 0.012 (ppm). The corresponding mean values in drainage water are 0.032, 0.430, 5.526, 0.337, 0.267 and $0.053 \mathrm{ppm}$ for $\mathrm{Cd}, \mathrm{Pb}, \mathrm{Ni}, \mathrm{Mn}, \mathrm{Zn}$ and $\mathrm{Cu}$, respectively.

Data in the same table illustrated that, some heavy metals contents in drainage water such as $(\mathrm{Cd}, \mathrm{Ni}, \mathrm{Mn}$ and $\mathrm{Zn})$ are higher than critical levels comparing with the contents of $\mathrm{Pb}$ and $\mathrm{Cu}$ in drainage water still less than the critical levels. Also, data in the same table showed that the critical levels of the studied heavy metals are $0.010,5.000,0.200,0.011,0.010$ and 0.200 (ppm) for $\mathrm{Cd}, \mathrm{Pb}, \mathrm{Ni}, \mathrm{Mn}, \mathrm{Zn}$ and $\mathrm{Cu}$, respectively. These levels according to FAO (1985). This could be attributed to the pollution sources of industrial (oil and soap factory) and municipal wastes discharged to the drainage system. Increasing the contents of some heavy metals in drainage water considers a great problem because in the studied area, the farmers were and still have to use this water in irrigation their different crops without any treatment because there isn't any alternative water source to irrigate their lands. So, this water must be treated to be safe for using to irrigate other crops, but, this kind of water must be forbidden to irrigate vegetable crops because irrigation these crops is very dangerous on human being health. Also, using this kind of water in irrigation polluted the soil and makes it unsuitable place to grow crops in it. these results are in a great harmony with those obtained by Zein et al. (1998), Zein et al. (2002), Zein et al. (2012), Atwa et al. (2013) and Abeguynrin et al. (2013).

\section{DTPA-extracted heavy metals from studied soils:}

Presented data in Table (4) clearly showed that the mean values of the DTPA-extractable heavy metals of the studied soil were higher after harvesting in comparison with before planting under all water quality treatments $W_{1}, W_{2}$ and $W_{3}$ where the mean values after harvesting are 0.148 , $3.30,0.871,11.54,2.83$ and $4.66 \mathrm{mg} / \mathrm{kg}$. The corresponding mean values before planting are $0.129,3.09,0.788,10.49,2.34$ and $4.31 \mathrm{mg} / \mathrm{kg}$ for $\mathrm{Cd}$, $\mathrm{Pb}, \mathrm{Ni}, \mathrm{Mn}, \mathrm{Zn}$ and $\mathrm{Cu}$, respectively. Concerning with the effect of irrigation water quality treatments. The highest mean values were recorded under $\mathrm{W}_{3}$ comparing with $W_{2}$ and $W_{1}$ either after harvesting or before planting. Generally, the mean values of the studied heavy metals can be descended before planting and after harvesting in order $W_{3}>W_{2}>W_{1}$. The mean values of DTPA. Extractable heavy metals can be descended harvesting in order $\mathrm{Mn}$ $>\mathrm{Cu}>\mathrm{Pb}>\mathrm{Zn}>\mathrm{Ni}>\mathrm{Cd}$. The mean values before planting are 10.49, 4.31, $3.09,2.34,0.788$ and 0.129 . While, the corresponding mean values after harvesting are $11.54,4.66,3.30,2.83,0.871$ and $0.148 \mathrm{mg} / \mathrm{kg}$, respectively. 
Data in the same Table clearly illustrated that, the mean values of DTPAextractable heavy metals either before planting and after harvesting are less than normal concentrations for these heavy metals which are 3-8, 100-400, $100,150-300,70-400$ and $60-125 \mathrm{mg} / \mathrm{kg}$ for $\mathrm{Cd}, \mathrm{Pb}, \mathrm{Ni}, \mathrm{Mn}, \mathrm{Zn}$ and $\mathrm{Cu}$, respectively.

Table (4): Effect of water quality on heavy metals contents of DTPA-soil $(\mathrm{mg} / \mathrm{kg})$ extract before planting and after harvesting of wheat cultivars.

\begin{tabular}{|c|c|c|c|c|c|c|}
\hline \multirow{2}{*}{ Water quality } & \multicolumn{7}{|c|}{ DTPA-extractable heavy metals (mg/kg) } \\
\cline { 2 - 7 } & $\mathbf{C d}$ & $\mathbf{P b}$ & $\mathbf{N i}$ & $\mathbf{M n}$ & $\mathbf{Z n}$ & $\mathbf{C u}$ \\
\hline \multicolumn{7}{|c|}{ Before planting } \\
\hline $\mathrm{W}_{1}$ & 0.097 & 2.73 & 0.678 & 7.98 & 1.56 & 3.82 \\
\hline $\mathrm{W}_{2}$ & 0.124 & 2.91 & 0.781 & 10.35 & 2.11 & 4.39 \\
\hline $\mathrm{W}_{3}$ & 0.165 & 3.63 & 0.905 & 13.14 & 3.36 & 4.71 \\
\hline Mean & 0.129 & 3.09 & 0.788 & 10.49 & 2.34 & 4.31 \\
\hline \multicolumn{7}{|c|}{ After harvesting } \\
\hline$W_{1}$ & 0.106 & 2.78 & 0.725 & 8.43 & 2.05 & 3.93 \\
\hline$W_{2}$ & 0.146 & 3.19 & 0.863 & 11.84 & 2.53 & 4.75 \\
\hline$W_{3}$ & 0.192 & 3.94 & 1.024 & 14.36 & 3.91 & 5.31 \\
\hline Mean & 0.148 & 3.30 & 0.871 & 11.54 & 2.83 & 4.66 \\
\hline $\begin{array}{c}\text { Normal } \\
\text { concentration }\end{array}$ & $3-8$ & $100-400$ & 100 & $150-300$ & $70-400$ & $60-125$ \\
\hline
\end{tabular}

According to Kabata-Pendias and Pendias (1992)

Data in the same Table illustrated that, the lowest mean values for the studied heavy metals either before planting or after harvesting were recorded under irrigation water quality $W_{1}$. On the contrary, the highest mean values were recorded under irrigation water quality $W_{3}$ both before planting and after harvesting. These findings and conclusions are in a great harmony with those obtained by Zein et al. (1998), Zein et al. (2002), Amany, Sallam et al. (2008), Zein et al. (2012), Atwa et al. (2013) and Seema Sahay et al. (2013). Aboulroos et al. (1991) who found that the behaviour of $\mathrm{Fe}, \mathrm{Mn}, \mathrm{Zn}$, $\mathrm{Cu}$ and $\mathrm{Pb}$ differ from that of $\mathrm{Cd}$, $\mathrm{Co}$ and $\mathrm{Ni}$ in soils irrigated with sewage effluent, they added that in $\mathrm{Cd}$, Co and Ni heavy metals, the percentages held in primary minerals fraction were increased with time on the expense of the percentage of other fractions especially that organically complexed. Although, the studied soils were still beyond the critical levels, it could be reached these upon the continuous using of low quality water.

Studied wheat cultivars:

Once the ions have been absorbed through the roots and have been transported to the xylem vessels, there is possibility of movement throughout the whole plant. The rate and extent of movement within plants depends on the metal concerned, the plant organ and the age of plant (Alloway, 1995).

The data of heavy metals concentration in grain, straw of studied wheat cultivars and coefficient of their translocation (TC) from straw to grain $(\mathrm{TC})=$

$\frac{\text { Content of heavy metal in grains }(\mathrm{mg} / \mathrm{kg})}{\text { Content of the same heavy metals in straw }(\mathrm{mg} / \mathrm{kg})} \times 100$


are presented in Table (5) and illustrated in Fig. (1). Data revealed generally that the studied heavy metals content; $\mathrm{Cd}, \mathrm{Pb}, \mathrm{Ni}, \mathrm{Mn}, \mathrm{Zn}$ and $\mathrm{Cu} \mathrm{mg} / \mathrm{kg}$ dry matter increased in grains and straw of the four studied wheat cultivars using polluted drainage water $\left(\mathrm{W}_{3}\right)$ for irrigation compared to that irrigated with mixed water $\left(W_{2}\right)$ and that irrigated with Nile water $\left(W_{1}\right)$. The data in the same table showed the sequence of heavy metals concentration in the straw $(\mathrm{mg} / \mathrm{kg})$, as follows:

$\begin{array}{lllllllll}\text { Order } & 1 & 2 & 3 & 4 & 5 & 6 & & \\ \text { Sequence } & \mathrm{Mn}>\mathrm{Zn}>\mathrm{Cu}>\mathrm{Pb}>\mathrm{Ni}>\mathrm{Cd} & \text { Nile water } & \mathrm{W}_{1} \\ 1^{\text {st }} & \mathrm{Mn}>\mathrm{Zn}>\mathrm{Pb}>\mathrm{Cu}>\mathrm{Ni}>\mathrm{Cd} & \text { Mixed water } & \mathrm{W}_{2} \\ 2^{\text {nd }} & \mathrm{Mn} & \mathrm{Mn}>\mathrm{Pb}>\mathrm{Zn}>\mathrm{Cu}>\mathrm{Ni}>\mathrm{Cd} & \text { Drainage water } & \mathrm{W}_{3} \\ 3^{\text {rd }} & \mathrm{Mn}>\mathrm{Pb}\end{array}$

Meanwhile, their contents in grains $(\mathrm{mg} / \mathrm{kg}$ ) were as the following sequence: $\mathrm{Mn}>\mathrm{Zn}>\mathrm{Cu}>\mathrm{Pb}>\mathrm{Ni}>\mathrm{Cd}$ for all water qualities. It can be clearly noticed that heavy metals content sequence of grains is identical to the sequence of straw for the Nile water qualities $\left(1^{\text {st }}\right.$ sequence). While, in the $2^{\text {nd }}$ and $3^{\text {rd }}$ sequences of heavy metals content in straw, $\mathrm{Pb}$, order changed from order 4 in the sequence of Nile irrigation water to order 3 in the sequence of mixed water $2^{\text {nd }}$ to order 2 in the sequence at the drainage water $3^{\text {rd }}$. In broad terms there is a positive trend between the concentration of $\mathrm{Pb}$ in both water and soil and that in the plant. Data in Table (5) showed that the lead content in both grain and straw increased by mixed and drainage water qualities. This may be due to the higher $\mathrm{Pb}$ content of drainage water than that of Nile water and the higher Pb-DTPA extractable in soil irrigated by drainage water. ElSanafawy (2002) and Zein et al. (2012) found that the main sources of Pb in water, soil and plants are mainly related to the waste water of some factories as Oil and Soap factories. They also added that the most amount of $\mathrm{Pb}$ was associated with soluble, exchangeable carbonate specifically and hydroxides fractions. In the present study, the input of $\mathrm{Pb}$ with drainage water, which polluted from Oil \& Soap wastes of Kafr El-Sheikh, absorbed by plant tissues from the drainage water.

In addition, data of translocation coefficient in Table 5 showed that $\mathrm{Pb}$ are the least. These results are in good agreement with the classification of Chaney and Giordane (1977) and Seema Sahay et al. (2013) who classified $\mathrm{Pb}$ as one of the least translocated elements within the plant. They concluded that translocation highly dependent on the physiological status. They added that, under conditions of optimal growth, $\mathrm{Pb}$ precipitates on root cell-walls in an insoluble amorphous form which, in maize, has been identified as a $\mathrm{Pb}$ phosphate.

El-Gendi et al. (1999) concluded that the tested metals; $\mathrm{Cd}, \mathrm{Pb}, \mathrm{Ni}$ and $\mathrm{Cu}$ have the ability to be absorbed by maize roots and may be remobilized to grains (except $\mathrm{Pb}$ to somewhat) which was slightly translocated from foliage to grains. On the other hand, Eissa and El-Kassas (1999) found that the concentration of $\mathrm{Cu}, \mathrm{Zn}, \mathrm{Mn}, \mathrm{Pb}, \mathrm{Cd}$ and $\mathrm{Ni}$ in roots were always higher than those of shoots or fruits. They concluded that this may indicate the immobility of these elements. These results are in the same line with those obtained by Amany, et al. (2008). 
Table (5): Effect of irrigation water quality on heavy metals content of wheat plants $(\mathrm{mg} / \mathrm{kg}$ dry weight) and their translocation coefficient (TC).

\begin{tabular}{|c|c|c|c|c|c|c|c|}
\hline \multirow[t]{2}{*}{$\mathbf{f}$} & \multirow{2}{*}{$\begin{array}{l}\text { Wheat } \\
\text { cultivar }\end{array}$} & \multicolumn{6}{|c|}{ Heavy metal (mg/kg dry weight) } \\
\hline & & Cd & $\mathrm{Pb}$ & $\mathrm{Ni}$ & Mn & $\mathrm{Zn}$ & $\mathrm{Cu}$ \\
\hline & & \multicolumn{6}{|c|}{ Grain } \\
\hline \multirow[t]{4}{*}{$\mathrm{W}_{1}$} & Misr-1 & 0.067 & 0.09 & 0.22 & 35.86 & 4.30 & 1.04 \\
\hline & Misr-2 & 0.067 & 0.09 & 0.08 & 35.32 & 3.42 & 0.88 \\
\hline & Sakha 94 & 0.079 & 0.17 & 0.27 & 35.99 & 4.17 & 1.19 \\
\hline & Sakha 93 & 0.075 & 0.73 & 0.28 & 36.40 & 4.03 & 0.99 \\
\hline \multicolumn{2}{|c|}{ Mean } & 0.072 & 0.27 & 0.21 & 35.89 & 3.98 & 1.00 \\
\hline \multirow[t]{4}{*}{$\mathrm{W}_{2}$} & Misr-1 & 0.086 & 0.43 & 0.34 & 38.01 & 4.36 & 1.05 \\
\hline & Misr-2 & 0.070 & 0.19 & 0.32 & 37.61 & 3.85 & 0.87 \\
\hline & Sakha 94 & 0.088 & 0.73 & 0.54 & 36.80 & 4.73 & 1.27 \\
\hline & Sakha 93 & 0.091 & 1.17 & 0.86 & 40.70 & 4.61 & 0.98 \\
\hline \multicolumn{2}{|c|}{ Mean } & 0.084 & 0.63 & 0.52 & 38.28 & 4.39 & 1.04 \\
\hline \multirow[t]{4}{*}{$\mathrm{W}_{3}$} & Misr-1 & 0.087 & 1.18 & 0.84 & 38.82 & 5.08 & 1.55 \\
\hline & Misr-2 & 0.077 & 1.14 & 0.74 & 38.95 & 4.41 & 1.16 \\
\hline & Sakha 94 & 0.108 & 1.72 & 1.25 & 42.71 & 5.19 & 1.97 \\
\hline & Sakha 93 & 0.124 & 2.02 & 1.10 & 42.18 & 4.76 & 1.97 \\
\hline \multicolumn{2}{|c|}{ Mean } & 0.099 & 1.52 & 0.98 & 40.67 & 4.86 & 1.66 \\
\hline & & \multicolumn{6}{|c|}{ Straw } \\
\hline \multirow[t]{4}{*}{$\mathrm{W}_{1}$} & Misr-1 & 0.239 & 6.41 & 4.39 & 64.79 & 16.90 & 7.04 \\
\hline & Misr-2 & 0.259 & 5.40 & 2.73 & 50.29 & 14.29 & 7.97 \\
\hline & Sakha 94 & 0.329 & 5.40 & 4.93 & 58.29 & 16.47 & 7.41 \\
\hline & Sakha 93 & 0.269 & 8.91 & 4.74 & 58.28 & 15.54 & 6.90 \\
\hline \multicolumn{2}{|c|}{ Mean } & 0.297 & 6.53 & 4.20 & 57.91 & 15.80 & 7.08 \\
\hline \multirow[t]{4}{*}{$\mathrm{W}_{2}$} & Misr-1 & 0.329 & 10.57 & 5.23 & 65.12 & 17.90 & 8.27 \\
\hline & Misr-2 & 0.289 & 9.57 & 3.40 & 69.46 & 17.00 & 8.82 \\
\hline & Sakha 94 & 0.299 & 17.74 & 9.23 & 54.45 & 17.39 & 8.51 \\
\hline & Sakha 93 & 0.379 & 21.74 & 7.73 & 64.79 & 20.19 & 7.99 \\
\hline \multicolumn{2}{|c|}{ Mean } & 0.324 & 14.91 & 6.40 & 63.46 & 18.12 & 8.40 \\
\hline \multirow[t]{4}{*}{$W_{3}$} & Misr-1 & 0.319 & 28.58 & 5.73 & 77.96 & 19.57 & 9.32 \\
\hline & Misr-2 & 0.299 & 22.07 & 6.40 & 78.46 & 17.95 & 9.66 \\
\hline & Sakha 94 & 0.429 & 18.94 & 11.06 & 59.62 & 21.44 & 9.24 \\
\hline & Sakha 93 & 0.469 & 21.07 & 8.73 & 68.96 & 20.75 & 8.47 \\
\hline \multicolumn{2}{|c|}{ Mean } & 0.379 & 22.67 & 7.98 & 71.25 & 19.93 & 9.17 \\
\hline \multicolumn{2}{|c|}{ Critical level } & $0.2-0.8$ & $0.1-10$ & 1.0 & $15-1000$ & $15-200$ & $4-15$ \\
\hline & & \multicolumn{6}{|c|}{ Translocation coefficient from grain to straw. } \\
\hline $\mathrm{W}_{1}$ & Misr-1 & 28.03 & 1.40 & 5.01 & 55.35 & 25.44 & 14.77 \\
\hline & Misr-2 & 25.87 & 1.67 & 2.93 & 70.23 & 23.93 & 11.04 \\
\hline & Sakha 94 & 24.01 & 3.15 & 5.48 & 61.74 & 25.32 & 16.06 \\
\hline & Sakha 93 & 27.88 & 8.19 & 6.26 & 62.25 & 25.93 & 13.04 \\
\hline & $\operatorname{an}$ & 26.45 & 3.60 & 4.91 & 62.39 & 25.15 & 13.73 \\
\hline $\mathrm{W}_{2}$ & Misr-1 & 26.14 & 4.07 & 6.50 & 58.37 & 24.36 & 12.70 \\
\hline & Misr-2 & 24.22 & 1.99 & 9.41 & 54.15 & 22.65 & 9.86 \\
\hline & Sakha 94 & 29.43 & 4.11 & 5.85 & 67.85 & 27.20 & 14.92 \\
\hline & Sakha 93 & 24.01 & 5.38 & 11.13 & 62.82 & 22.83 & 12.27 \\
\hline & $\operatorname{an}$ & 27.70 & 3.89 & 8.22 & 60.80 & 24.26 & 12.44 \\
\hline$W_{3}$ & Misr-1 & 27.27 & 4.13 & 14.66 & 49.79 & 25.95 & 16.63 \\
\hline & Misr-2 & 25.75 & 5.17 & 11.56 & 49.64 & 24.57 & 12.01 \\
\hline & Sakha 94 & 25.17 & 9.81 & 11.30 & 71.64 & 24.56 & 21.13 \\
\hline & Sakha 93 & 26.44 & 9.59 & 12.60 & 61.17 & 22.94 & 23.26 \\
\hline & $\operatorname{an}$ & 26.17 & 7.18 & 12.53 & 58.06 & 24.51 & 18.27 \\
\hline & l level & 26.74 & 4.89 & 8.55 & 60.42 & 24.41 & 14.81 \\
\hline
\end{tabular}


Data of Ni concentration in grain and straw yield $(\mathrm{mg} / \mathrm{kg})$ and translocation coefficient in Table (5) indicated that Ni values increased in drainage water quality than the other two qualities, this is due to its higher content of polluted drainage water from oil and soap factory.

Translocation coefficient values ranged between 2.93 and 14.65 with an average of $8.79 \%$ indicating its intermediate status relative to other studied heavy metals. This is found to be in good agreement with the classification of Chaney and Giordano (1977) for heavy metals translocation.

Duneman et al. (1991) found that the concentration of Ni plants, reflects the concentration of the element in the soil, although the relationship is clearly more directly related to the concentration of soluble ions of $\mathrm{Ni}$ and rate of replenishment of this mobile pool. These results are in agreement with those obtained by El-Sanafawy (2002), Atwa et al. (2013) and Abeguynrin et al. (2013).

Concentration of $\mathrm{Zn}$ and $\mathrm{Cu}$ in the studied wheat cultivars under different water qualities and their translocation coefficients are presented in Table (5). It is clear that the two elements have the same trend. The mean concentration values of $\mathrm{Zn}$ and $\mathrm{Cu}$ increased in the straw from $15.80 \mathrm{mg} / \mathrm{kg}$ and $7.08 \mathrm{mg} / \mathrm{kg}$ at Nile water qualities to $18.12 \mathrm{mg} / \mathrm{kg}$ and $8.40 \mathrm{mg} / \mathrm{kg}$ at mixed water quality and $19.93 \mathrm{mg} / \mathrm{kg}$ and $9.17 \mathrm{mg} / \mathrm{kg}$ at drainage water qualities, respectively. While, the mean values were $3.98 \& 1.00,4.39 * 1.04$, $4.86 \& 1.66 \mathrm{mg} / \mathrm{kg}$ at $\mathrm{W}_{1}, \mathrm{~W}_{2}$ and $\mathrm{W}_{3}$ qualities for $\mathrm{Zn} \& \mathrm{Cu}$ in grains, respectively.

Data in Table 5 indicate hat concentration of $\mathrm{Zn}$ values are generally higher than the corresponding $\mathrm{Cu}$ concentration in grain and straw of studied wheat cultivars, in spite of, Cu-DTPA extractable of the studied soils were greater than that of $\mathrm{Zn}$ content $(\mathrm{mg} / \mathrm{kg})$. This may be due to the higher content of $\mathrm{Ca}^{++}$in drainage water $(4.88 \mathrm{meq} / \mathrm{L}$ ), studied soils (ranged between 13.91 and $25.65 \mathrm{meq} / \mathrm{L}$ in soil paste extract and/or Cu retention to clay and organic matter.

The data of translocation coefficient (Table5) showed that $\mathrm{Zn}$ values are generally, greater than of $\mathrm{Cu}$ and this in agreement with those of Kabata Pendias and Pendias (1992) who found that, following root absorption, the extent to which elements are translocated decreases in the following order $\mathrm{Cd}>\mathrm{B}>\mathrm{Zn}>\mathrm{Cu}>\mathrm{Pb}$. These results are in agreement with those of Zein et al. (2002), Zein et al. (2012) and Saleh et al. (2013).

From data in Table (5), it seems that Mn has the highest values of all studied heavy metals content in both grain (ranged from 35.32 to 42.71 $\mathrm{mg} / \mathrm{kg}$ ) and straw (ranged from 50.29 to $78.46 \mathrm{mg} / \mathrm{kg}$ ) at the three studied water qualities for all tested cultivars. The data indicated also that the grain content value were lower than those of straw.

Data revealed that mean values of $\mathrm{Mn}$ content in grain and straw of wheat cultivars were higher when irrigated with polluted drainage water 40.67 and $71.25 \mathrm{mg} / \mathrm{kg}$ ) than that irrigated with mixed water (38.28 and 63.46 $\mathrm{mg} / \mathrm{kg}$ ), and that irrigated with Nile water $(35.89$ and $57.91 \mathrm{mg} / \mathrm{kg})$. These results are in agreement with those obtained by Eid and Shereif (1996) who revealed that $\mathrm{Mn}$ contents in plants were significantly affected by irrigation water, crop types and part of plant. They demonstrated that the maximum 
increase of $\mathrm{Mn}$ amounted to $18 \%$ in plants irrigated with mixed raw waste water 1:2 with fresh water, when compared to control (fresh water) irrigation. They also concluded that manganese contents in straw in all studied plants (barley, rapeseed and broadbean) were significantly higher than in grain and seeds. Data of translocation coefficient in the same table showed that Mn has the highest values of studied heavy metals and was not affected by water qualities. These results revealed the classification of Chaney and Giordano (1977) who classified Mn as one of readily translocated elements.

Cadmium values (Table 5) of grain and straw contents indicated that $\mathrm{Cd}$ has the lowest values in all studied heavy metals and ranged between 0.067 and $0.124 \mathrm{mg} / \mathrm{kg}$ for grains and between 0.239 and $0.469 \mathrm{mg} / \mathrm{kg}$ for straw. The averages of Cd content were $0.072,0.085$ and $0.099 \mathrm{mg} / \mathrm{kg}$ for grains and $0.297,0.324$ and $0.379 \mathrm{mg} / \mathrm{kg}$ for straw at $W_{1}, W_{2}, W_{3}$ water qualities, respectively.

Cadmium mean values of grain and straw content increased by 11.3 and $4.3 \%$ at $W_{2}$ and 23.5 and $16.1 \%$ at $W_{3}$ quality compared to $W_{1}$. These results are in partial agreement with those obtained by Homberg and Brumemr (1986) who found that $\mathrm{Cd}$ concentrations in wheat grain were linearly correlated with the total content of the soil. While, the straw data did not show the same linear trend.

This may be due to the high values of soil pH (8.2), higher content of soluble $\mathrm{Ca}^{++}$(14..20-25.9 meq/L in soil paste extract) and/or Zn-DTPA extractable (1.56-3..91 ppm). These conclusions are in agreement with those obtained by Alloway (1995) who found that the uptake of Cd by rice decreased when $\mathrm{pH}$ was increased from 5.5 to 7.5 and wheat showed a similar response, and also found that the addition of $\mathrm{CaO}$ to soils reduced the uptake of $\mathrm{Cd}$ by foder rape due to both an increase in $\mathrm{pH}$ and to competition between $\mathrm{Ca}^{++}$and $\mathrm{Cd}^{++}$ions, Oliver et al. (1994) who found that application of low rates of $\mathrm{Zn}$ fertilizer (up to 2.5 to $5.0 \mathrm{~kg} \mathrm{Zn} / \mathrm{ha}$ ) markedly decreased the $\mathrm{Cd}$ concentration in wheat grain. They added that no further significant decreases in $\mathrm{Cd}$ concentration in grain occurred at higher rates of applied $\mathrm{Zn}$, Page et al. (1981) who found that relative excess of $\mathrm{Cn}, \mathrm{Ni}$ and $\mathrm{Zn}$ can reduce the uptake of $\mathrm{Cd}$ by plants.

The data of $\mathrm{Cd}$ translocation coefficient (Table 5) showed that its values ranged between $24.01 \%$ and $29.43 \%$ with an average of $26.96 \%$. These results are greater than that obtained by Lubben and Saver Beck (1991) who indicated that, independent of the degree of soil contamination, only about $10 \%$ of the total absorbed $\mathrm{Cd}$ is translocated into the grain. They added that a greater part of its remains in the straw. But results of $\mathrm{Cd}$ translocation coefficient in this study still agreed with the classification of Chaney and Giordano (1977) who classified Cd as one of readily translocated elements. 
Fig. (1): Water, soil and plant grain and straw contents of studied heavy metals (ppm)

$\mathrm{W}_{1}=$ Nile water, $\mathrm{W}_{3}=$ Drainage water, $\mathrm{W}_{2}=\mathbf{5 0} \% \mathrm{~W}_{1}+\mathbf{5 0} \% \mathrm{~W}_{2}$

Data in Table (5) showed that all studied heavy metals accumulated to substantially higher concentration in straw than in grain of all studied wheat cultivars under all water qualities.

Data in the same table indicated that the studied heavy metals translocation from shoots to grain can be arranged according to mean values of translocation coefficient in the following decreasing sequence:

$\mathrm{Mn}>\mathrm{Cd}>\mathrm{Zn}>\mathrm{Cu}>\mathrm{Ni}>\mathrm{Pb}$ 
These results are in agreement with those of Chaney and Giordano (1977). They classified $\mathrm{Mn}, \mathrm{Cd}, \mathrm{Zn}$ as elements which were readily translocated to the plant tips, $\mathrm{Ni}, \mathrm{Co}$ and $\mathrm{Cu}$ were intermediate and $\mathrm{Pb}, \mathrm{Cr}$ and $\mathrm{Hg}$ were translocated to the least extent after absorption through the roots. These results are in harmony with those obtained by Zein et al. (2002); El-Sanafawy (2002) and Atwa et al. (2013).

Data in Table (5) indicated that grain of Misr-2 wheat cultivar had the lowest content of studied heavy metals under all water qualities followed by Misr-1 wheat cultivar. The straw of Misr-2 had also the lowest content of $\mathrm{Zn}$, $\mathrm{Cd}$ and $\mathrm{Pb}$ when irrigated with polluted drainage water. These results may be due to the differences in genetic constitution of the studied genotypes and/or the dilution effect phenomenon. This conclusion is in partial agreement with that of Shalaby et al. (1996) and Saleh et al. (2013) who concluded that increasing of heavy metal concentration in plants may be attributed either to the higher amounts, or to the opposite of the dilution effect phenemonenon, where the dry matter yield of the plants diminished with increasing the concentration of the applied wastes, consequently concentrate those heavy metals in the dry matter of those plants.

So, in conclusion, the study recommend the cultivar Misr-2 to be used in the lands irrigated with drainage water and in soils contaminated with heavy metals because it is least affected by heavy metals, high productive and moderately save for human food and livestock feed.

\section{REFERENCES}

Abd-Allah, M.E. (1995). Effect of irrigation with drainage water on some physical properties of soil and plant growth. M.Sc. Thesis, Fac. Agric., Menufiya Univ., Egypt.

Abeguynrin, T.P.; G.O. Awe; D.O. Idowu; O.O. Onigbogi and O.E. Onofua (2013). Effect of kitchen waste water irrigation on soil properties and growth of cucumber (Cucumis sativus). Journal of Soil Science and Environmental Management. 4(7): 139-145.

Aboulroos, S.A.; Sh.Sh. Halah; M.I. El-Kherbawy and E.H. Badawy (1991). Fractionation of some heavy metals in soils irrigated with sewage effluents for different years. Egypt. J. Soil Sci., 31(1): 43.

Alloway, B.J. (1995). "Heavy Metals in Soils", $2^{\text {nd }}$ Ed., Chapman and Hall, London.

Amany, M. Sallam; A.S. Khaled, and Mona A.M. Soluman (2008). Effect of irrigation water sources on productivity and grain quality of wheat. Third Environment Conference, Faculty of Science, Zagazig Univ., pp. 59-75.

Atwa, A.A.E.; N.I. Talha; E.S. El-Gizawy and Kh.A. Amer. (2013). Impact of water quality on barley varieties, soil properties and their contents of heavy metals. J. Soil Sci. and Agric. Eng. Mansoura Univ., 4(5): 463474.

Boussamo, B.; O.O. Uariti; A. Suzuki and M.H. Ghorbal (1999). Cadmium stress on nitrogen assimilation. Journal of Plant Physiology, 155: 310317. 
Chaney, R.L. and R.L.Giordano (1977). Soils for the management of organic wastes and waste water. In: L.F. Elliot and F.J. Stevenson. (Eds.) Soil Sci. Soc. Am., Am. Soc. Agron. \& Crop Sci. Soc. Am., Madison, 235279 (C.F. Alloway, 1995).

Chapman, H.D. and P.F. Pratt (1961). Methods of Analysis for Soils, Plants and Waters. Agr. Pub. Univ. of California, Riverside, U.S.A.

Duneman, L.; N. Von Wiren; R. Schulz; and H. Marschener (1991). Plant and soil, 133, 263.

Eid, M.A.and M.M. Shereif (1996). Effect of wastewater irrigation on mineral contents of certain crops (greenhouse conditions). Egypt. J. Sci., 3(14): 109.

Eissa, A.M. and H.I. El-Kassas (1999). Impact of heavy metals on soil, plant and water at Abou-Zaabal area. Egypt. J. Soil Sci., 39(3): 351.

El-Gendi, S.A.; A.H. Somaya; M. Abou-Sinna and N.F. Kandil (1999). Fractionation and accumulation of some heavy metals in soils and plants irrigated with sewage effluent. Egypt. J. Soil Sci., 39(2): 211.

El-Hawary, A. (2003). Added value knowledge report management practices for the drainage water reuse. AVKR-3 technical Report. Med. Rennet. II. (INCO-VI-453-502).

El-Mowelhi, N.M.; B.M. El-Nashar and A.F. El-Wakeel (1995). Quality aspects of the drainage water of Western Delta area. Conf. of an Farm Irrig. and Agroclimatology, Cairo, Egypt.

El-Sanafawy, Hamida, M. (2002). Geochemical investigation on soil and water on polluted areas in mid-Nile Delta for environmental assessment. Ph.D. Thesis, Fac. Sci., Mansoura Univ., Egypt, p. 248.

FAO (1973). Irrigation, Drainage and Salinity Intersource Book, $\mathrm{FAO} / \mathrm{UNESCO}$.

FAO (1985). Water quality for agriculture. In: R.S. Ayers and D.W. Westcot. Irrigation and Drainage, pp. 29, Rev. 1, Rome.

Frost, H.L. and L.H. Ketchum (2000). Trace metal concentration in durum wheat from application of sewage sludge and commercial fertilizer. Adv. Environ. Res. 4: 347-355.

Homberg, V. and G.W. Brumemr (1986). Cadmium availability in soils and content in wheat. In: M. Anke, H. Brounicih; C. Bruckner and B. Groppel (Ed.), Fifth Symposium on lodine and other elements. Schiller Univ., Dena 916 (Cited in Alloways, 1995).

Iman Saleh; Masoud, M.; Jahanshah, S. and Khabat, K. (2013). The effect of water quality and irrigation methods on moisture and salinity distribution of soil. International Journal of Advanced Biological and Biochemical Research, 1(7): 754-766.

Kabata Pendias A. and H. Pendias (1992). Trace elements in soils and plants. $2^{\text {nd }}$ ed. Lewis Pub. Boca Raton, Florida.

Lindsay, W.L. and W.A. Norvell (1978). Development of DTPA test for zinc, iron, manganese and copper. Soil Sci. Soc. Am. J. 42: 421-428.

Lubben, S. and D. Saver Beck (1991). The uptake and distribution of heavy metals by spring wheat. Water air and Soil Pollution, 57-58, 239. 
Mostafa, M.M. (2001a). Nutrition and productivity of broad bean plant as affected by quality and source of irrigation water. Zagazig J. Agric. Res., 28(3): 517-532.

Mostafa, M.M. (2001b). Nutrients uptake and dry matter yield of barley as affected by salinity of irrigation water and addition of organic material. Zagazig J. Agric., Res. 3: 122-129.

Oliver, D.P.; R. Hanam; K.G. Tiller; N.S. Wilhelm and G.D. Cozens (1994). Heavy metals in the environment the effects of zinc fertilization on cadmium concentration in wheat grain. J. Environ.. Qual., 23: 705.

Page, A.I.; F.T. Bigham and A.C. Chang (1981). In: Effect of heavy metal pollution on plants. Vol. $1,1^{\text {st }}$ ed., pp. 72-109, Lepp, N.W. Applied Science, London.

Richards, L.A. (1969). Diagnosis and Improvement of Saline and Alkali Soils. U.S. Dept. Agric. Handbook NO. 60.

Seema, S.; A. Inam and S. Iqbal (2013). Effect of wastewater irrigation on soil, metal tolerance and its remediation by four oil yield Brassica cultivars. International Journal of Environmental Sciences, 3(2).

Shalaby, M.H.; O.A. Gobran and M.I. Raslan (1996). Chemical properties of soils as affected by pollution of different wastes. J. Soil Sci., 36(1-4): 23.

Snedecor, G.W. and W.G. Cochran (1980). Statistical methods. $7^{\text {th }}$ Ed., 225330. lowa State Univ. Press. Ames., lowa, USA.

Voutsa, D.; A. Grimanis and C. Savora (1996). Trace elements in vegetables in an industrial area in relation to soil and air particulate matter. Environ. Pollut. 94: 325-335.

Zein, F.I. and S.S.M. Bader (2003). Evaluation of some Egyptian cotton varieties irrigated with different water qualities. Proc. $10^{\text {th }}$ Conf. Agron., Suez Canal Univ., Fac., Environ., Agric.Sci., El-Arish, Egypt, 1214-1224.

Zein, F.I.; Maani, Z. Abou Amou; A.A. El-Leithi and M.M. El-Shami (2002). Effect of polluted irrigation water on some crops and their contents of heavy metals. 1-Wheat Egypt. J. Soil Sci. 42(1): 139-159.

Zein, F.I.; N.I. Talha; Hamida, M.A. El-Sanafawy and I.A. El-Saiad (2012). Heavy metals content of some cotton genotypes and soil properties as affected by water quality. J. Soil Sci. and Agric. Eng. Mansoura Univ., 3(12): 1125-1136.

Zein, F.I.; O.A. Hegab and Hamida M. El-Sanafawy (1998) Geochemical studies on some polluted soils in Kafr El-Sheikh Governorate, Egypt. J. Agric. Sci. Mansoura Univ., 23(6): 2887-2918. 


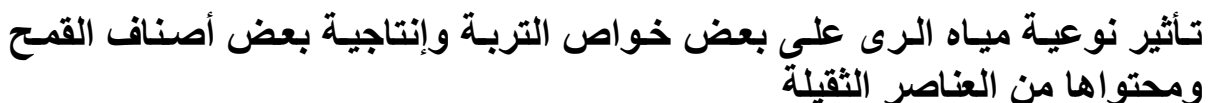

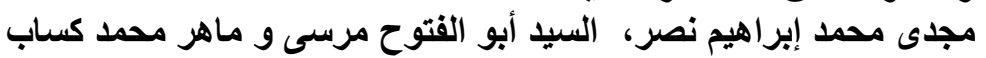

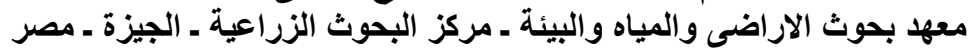

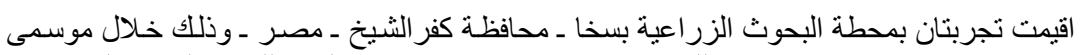

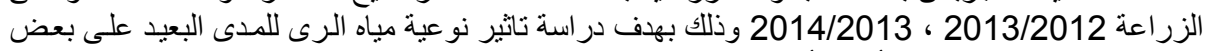

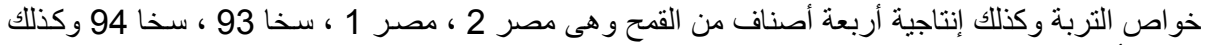

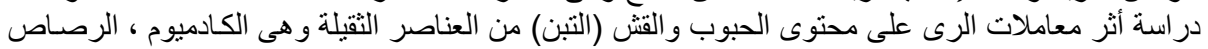

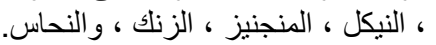

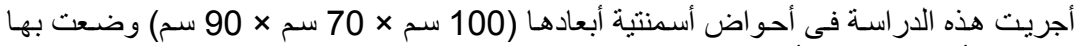

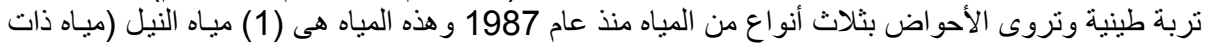

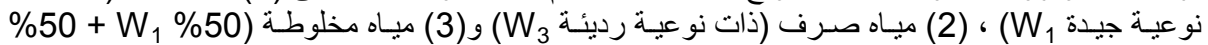

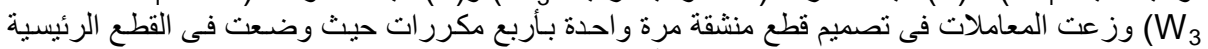

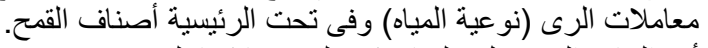

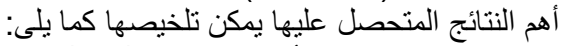

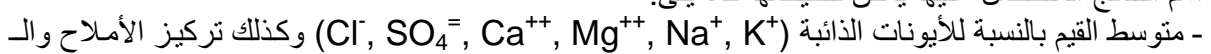

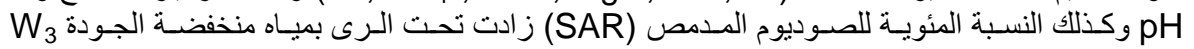

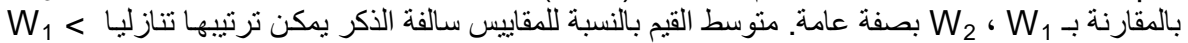

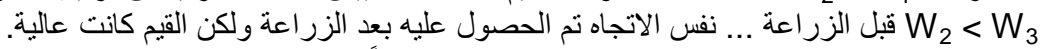

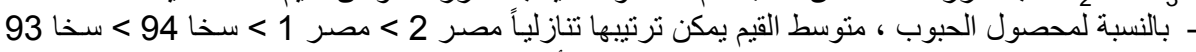

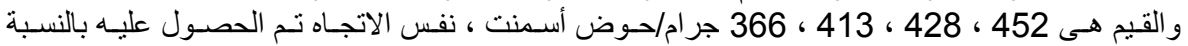

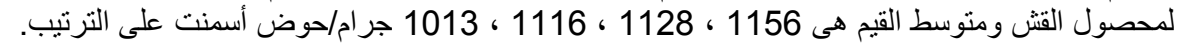

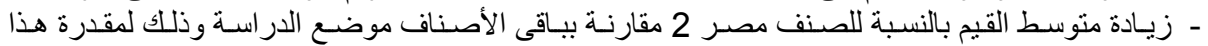
الصنف على تحمل الرى بمياه منخفضة الجودة وكذئل اللك المخلوطة

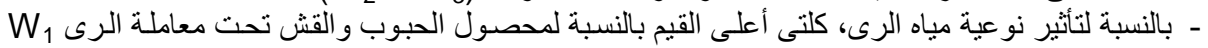
مقارنة

- بالنسبة لعملية استخلاص العناصر الثقيلة باستعمال DTPA وهى (Pb, Cd, Ni, Mn, Zn, Cu)

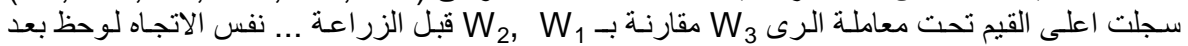

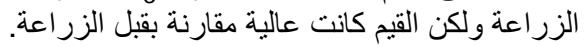

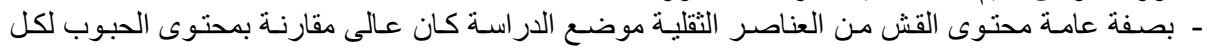

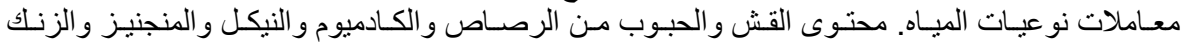

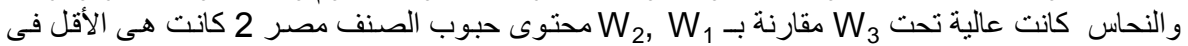

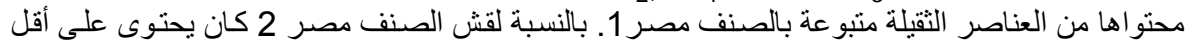
تركيز من Cd, Ni, Zn وذللك عندما تم استخدام مياه الصرف فئل الصن الرى. 